On Estimating the Size of the Shadow Economy

Gebhard Kirchgässner

February 2016 Discussion Paper no. 2016-03

School of Economics and Political Science, University of St.Gallen Department of Economics 


$\begin{array}{ll}\text { Editor: } & \text { Martina Flockerzi } \\ & \text { University of St.Gallen } \\ & \text { School of Economics and Political Science } \\ & \text { Department of Economics } \\ & \text { Bodanstrasse } 8 \\ & \text { CH-9000 St. Gallen } \\ & \text { Phone } \quad+41712242325 \\ & \text { Fax } \quad+41712243135 \\ & \text { Email seps@unisg.ch } \\ & \text { School of Economics and Political Science } \\ & \text { Department of Economics } \\ & \text { University of St.Gallen } \\ & \text { Bodanstrasse } 8 \\ \text { Publisher: } & \text { CH-9000 St. Gallen } \\ & \text { Phone +41 71 224 23 25 } \\ & \text { Fax +41 71 224 31 35 } \\ & \text { http://www.seps.unisg.ch }\end{array}$




\title{
On Estimating the Size of the Shadow Economy
}

\author{
Gebhard Kirchgässner ${ }^{1}$
}

Author's address:

Prof. em. Dr. Dr. h.c. Gebhard Kirchgässner

University of St. Gallen

SIAW-HSG

Bodanstrasse 8

$\mathrm{CH}-9000$ St. Gallen

Email gebhard.kirchgaessner@unisg.ch

\footnotetext{
${ }^{1}$ Universität St. Gallen, Schweizerisches Institut für Aussenwirtschaft und Angewandte Wirtschaftsforschung, Leopoldina, CESifo and CREMA.
} 


\begin{abstract}
As long as it is employed cautiously enough, the model approach is a useful tool to estimate simultaneously the size and the development of the shadow economy in several countries. However, a second method is necessary to calibrate the model. The currency demand approach can lead to highly implausible results; the size of the shadow economy might be largely overestimated. An alternative is the survey method. For real tests of whether a variable has an impact, procedures are necessary that do not use the same variables as those used to construct the indicator. Thus, to make progress in analysing the shadow economy, the model approach has a role to play, but it has to be complemented by other methods employing different data. The currency demand approach cannot be used as long as it employs the same variables for its constructions.
\end{abstract}

\title{
Keywords
}

Shadow Economy, Model Approach, Currency Demand Approach, Survey Methods, Tax Burden, Testing, Plausibility Tests.

\section{JEL Classification}

O17, C18. 


\section{Introduction}

[1] Since the discussion about the size of the black economy ${ }^{1)}$ started in the 1970s with the papers by P.M. GUTMAnN (1977) and E.L. FeIGE (1979), ${ }^{2)}$ various approaches have been developed "to measure the unmeasurable" (L.P. FELD, A.J. SCHMIDT and F. SCHNEIDER (2011, p. 314)). ${ }^{3)}$ Three approaches dominate the literature: as a 'direct procedure' the survey method first applied by A.J. ISACHSEN, J.T. KLOVLAND and S. STRøM (1982), ${ }^{4)}$ and as 'indirect procedures' the modified currency demand approach first applied by V. TANZI (1980) and J.T. KLOVLAND (1984), ${ }^{5)}$ and the model approach dating back to H. WECK (1983) and B.S. FREY and H. WeCK-HANNEMANN (1984). The latter is today mainly applied by F. SCHNEIDER (together with many co-authors), who provides estimates for (at least) 145 countries all over the world and sometimes even for states in federal countries. ${ }^{6)}$ Today, he truly dominates the field. ${ }^{7)}$

[2] The different approaches lead to very different results. The smallest numbers are generally provided by the survey method and rather high ones by the currency demand approach, while the model approach only provides a structure; to derive figures, the estimated model has to be calibrated using another method. Normally, the currency demand approach is employed. Thus, the estimates presented with the model approach are also rather high. L.P. FELD and F. SCHNEIDER (2010, p. 125), for example, provide estimates for Germany in the year 2006 of 5 to 6 per cent of the GDP using the survey method but 15 per cent using the model approach. They intend to make these data consistent by adding to the results of the survey method 3 to 4 per cent of the GDP due to material (used in the black economy), 4 to 5 per cent for illegal activities and 1 to 2 per cent for illegal activities already included in the official GDP. Thus, they arrive at a figure of between 13 and 17 per cent of the GDP. Leaving aside the problem that they do not provide any source for these additional figures, a great deal of double counting is involved.

1. I use the terms black economy, underground economy and shadow economy synonymously. I include all activities which - given our conventions - should be but are not counted in the official GDP figures, be it (pure) tax evasion, clandestine work or criminal activities, as long as the latter are 'productive'. Thus, following the usual convention, I do not consider homework or (legal) do-it-yourself activities as part of it. See for this distinction also F. SCHNEIDER and D.H. ENSTE (2002, p. 11) who distinguish between the (legal) selfsufficient economy and the (illegal) shadow economy, or A. BUEHN, A. KARMANN and F. SCHNEIDER (2009) who distinguish between the shadow economy and do-it-yourself activities which both belong (in their terminology) to the hidden economy.

2. A much earlier contribution was already presented by P. JosTOCK (1943).

3. For early overviews see G. KIRCHGÄSSNER (1984) or B.S. FrEY and W.W. POMMEREhNE (1984), for more recent ones F. SCHNEIDER and D. H. ENSTE (2000) or B. KAZEMIER (2006).

4. A forerunner for Germany is INSTITUT FÜR DEMOSKOPIE (1975).

5. Currency demand equations have first been estimated by P. CAGAN (1958), but he did not yet use these for estimating the size of the shadow economy.

6. See for example, F. Schneider (2005, 2005a), A. BueHn and F. Schneider (2012), or, for the Austrian Bundesländer, F. SCHNEIDER (2015a).

7. Among his very many publications see, for example, F. SCHNEIDER and D. H. ENSTE (2000, 2002), F. SCHNEIDER (2005, 2011, 2015) or D. H. ENSTE and F. SCHNEIDER (2006). 
[3] The material used by illicit workers is usually bought in legal shops, produced by legally operating firms and, therefore, included in the official GDP figures. ${ }^{8)}$ If it would be produced and/or traded on the black market, it should be included in the results of the survey method. The latter also holds for the black activities included in the official GDP. There is no rationale for why, when estimating the size of the shadow economy, the statistical offices should consider totally different activities from those about which people are asked in surveys. This does not hold for those illegal (often foreign) illicit workers in restaurants or in the construction industry. Their productive activities are hardly reflected in the surveys but belong to the shadow economy as long as their output is not reflected in the official statistics.

[4] Another problem is criminal activities. They belong to the shadow economy as long as they are 'productive'. This holds, for example, for illegal banking, illegal lotteries or prostitution. Theft and robbery, on the other side, are simple redistribution and not production. Trivially, capital crimes are also not production and, therefore, not part of the shadow economy. Therefore, only parts of criminal activities belong to the shadow economy; they can hardly fill the gap between the figures produced with the model/currency demand approach and those produced with the survey method. Thus, it seems to be impossible to make the results of these two approaches consistent.

[5] Moreover, the figures presented by L.P. FELD and F. SCHNEIDER (2010) for the survey method are themselves rather high. To my knowledge, the only available survey data for Germany for the year 2006 are from the Rockwool Foundation Research Unit in Copenhagen ${ }^{9)}$ and the results are published, for example, in L.P. FELD and C. LARSEN (2012, p. 22). Depending on the concrete approach, they obtain a figure of 0.60 per cent or 1.83 per cent of the GDP, respectively. ${ }^{10)}$ That year might, however, have been an outlier; the estimates are considerably lower than those in other years. But the picture does not change dramatically if we consider the mean of the years 2004 to 2008. We then obtain values of 0.95 or 2.8 in relation to the GPD, respectively. Taking these figures into account, the discrepancy between the results of the different approaches becomes even larger. It is hardly believable that the illegal activities not captured in the official GDP can fill this gap.

[6] One might argue that the survey method provides a lower bound and the model/currency demand method an upper bound of the possible values. However, the difference between 1 to 3 and 15 per cent of the GDP is too large to draw any conclusion: the shadow economy might be negligibly small or dramatically large.

[7] Trivially, we do not know the true values. Otherwise, the whole exercise would be superfluous. What we can do, though, is to perform plausibility checks. We will perform such checks for Germany, using the survey and the model/currency demand approaches. We will base these considerations on L.P. FELD and F. SCHNEIDER (2010) for the model/currency demand approach

8. It might be an indicator of - legal - do-it-yourself activities, which are typically not included in the shadow economy. Moreover, this holds only for the share that is not due to clandestine work. It might be difficult to draw a clear line, but this only reinforces the suggestion that the volume of these sales can hardly be employed as an indicator for the black economy.

9. See http://www.rockwoolfonden.dk/publications/undeclared+work (09/12/15).

10. See also L. P. FELD and C. LARSEN (2012a, p. 58f.). 
and on L.P. FELD and C. LARSEN (2005, 2012, 2012a) for the survey method. To reduce the considerable impact of sampling (and other measurement) errors in the surveys, we will build our calculations on the average of the years 2001 to 2008 for which data are provided in these papers.

[8] In the following, we will discuss problems of the survey method (Section 2), the model approach (Section 3) and the currency demand approach (Section 4). Then, applying these approaches, we will perform some plausibility checks for Germany in the year 2005 (Section 5). It will be shown that the estimates based on the combination of the model and the currency demand approach are highly implausible. We will also provide estimates for the German shadow economy from 1989/1990 to 2007, based on the model approach but calibrated with the survey method. They are much smaller (and much more plausible) than those employing the currency demand method. Our conclusion is that the model approach has a role to play, but to produce plausible estimates, the survey method should be used for calibration, and to check whether, for example, the tax burden has an impact on the shadow economy, alternative procedures have to be used that do not employ these variables in constructing the indicator for the shadow economy (Section 6).

\section{The Survey Approach}

[9] In the surveys produced for the Rockwool Foundation Research Unit in Copenhagen, the subjects were first asked whether they have carried out activities in the black economy during the last twelve months. ${ }^{11)}$ Those who affirmed that they have were asked how many hours per week they spent on these activities. They were also asked for their average wage per hour. This allows the calculation of the number of hours worked and the wage bill in the black economy for that year. The problem is how to translate these figures into a value that can be compared with the official GDP.

[10] L.P. FELD and C. LARSEN (2012a, pp. 57ff.) propose two methods. First, they compare the average undeclared working hours per week as a proportion of the declared working hours. Based on the assumption that the average labour productivity is the same in the official and the shadow economy, they arrive at a size of the latter of 2.85 per cent of the official economy. Second, they calculate the extent of undeclared work at the actual wages paid in the shadow economy as a proportion of the GDP. This leads to a value of 1.49 per cent. Taking into account the fact that undeclared work (as measured by the survey) covers only part of the undeclared activities and relying on some earlier Scandinavian studies, they multiply these figures by 1.44, resulting in 4.10 and 2.15 per cent, respectively.

[11] The problem with the first approach is the assumption that the average labour productivity is the same in the shadow as in the official economy. This is hardly plausible. The shadow economy exists mainly in the area of services. Take for example services in the tourism industry, private lessons given by teachers or the painting of walls by clandestine workers. There, the role of capital is relatively low and, correspondingly, the average labour productivity, that 
is, the relation between the value of the product and the value of the labour employed, is relatively small. Thus, the second approach based on the actual wages in the black economy seems to be rather justifiable. Not least, economic theory tells us that in such a truly unregulated labour market the wages should be equal to the marginal productivity and, given the low weight of capital in these processes, the marginal productivity should not be too far away from the average productivity. Even accepting the assumption of L.P. FELD and C. LARSEN (2012a) that this might only be a lower bound and, therefore, multiplying the figure by 1.44 leads to very low figures compared with those of the model approach.

\section{The Model Approach}

[12] As mentioned above, the model approach dating back to H. WECK (1983) and B.S. FREY and H. WECK-HANNEMANN (1984) is the one that is mostly employed by F. SCHNEIDER and his co-authors. ${ }^{12)}$ Moreover, most figures about the size of the shadow economies in all the parts of the world are based on this approach. There are good reasons for this. It is the easiest to handle and most convenient approach to estimate the developments of the shadow economies in many countries. One does not have to examine the details of the different countries; it is sufficient to use macro data that are easily available and sometimes data from international surveys as well.

[13] But this is not without costs. An obvious problem is the assumption that the same coefficients hold for all countries, that is, that the marginal effects are the same in all countries. It is at least not unreasonable to assume that the impact of high taxes in Scandinavian countries is different, for example, from that in Italy or Greece. On the other hand, such assumptions are common in most cross-country studies and hardly ever tested.

[14] This approach, however, contains two more important problems. First, as mentioned above, the estimations produce only relative weights. Thus, another method is necessary to 'normalise' the estimates; their validity depends on the reliability of this second method. These methods typically rely on additional untestable assumptions. Second, it is impossible to draw statistically confirmed conclusions about causal relations in the real world, not in the estimated model, from these estimates. ${ }^{13)}$

[15] A necessary condition for testing whether a variable $x$ has a causal impact on a variable $\mathrm{y}$ is that the two variables are measured independently. The model approach assumes that causal relations exist and, therefore, estimates a linear combination of these (supposedly) causal variables that more or less fits several indicator variables. This linear combination is assumed to be a representation of the unknown variable 'black economy'. This is entirely legitimate, but it is an empirical test neither of the existence (or extent) of this economy nor of whether the causal variables really have an impact on the 'true' underground economy. Significant test statistics in the structural model only show that the explanatory variables employed contribute significantly to the variance of the constructed variable. We have to assume that this construction

12. It is often called (DY)MIMIC approach: (Dynamic) Multiple Indicators, Multiple Causes. See, for example, L.P. FELD and F. SCHNEIDER (2011, pp. 126ff.) or F. SCHNEIDER (2005).

13. See also the critiques of J. SLEMROD and C. WEBER (2012) and of E.L. FEIGE (2015) of the model approach. 
represents the black economy to make statements about possible causal relations. However, this assumption should be tested, and this test cannot be undertaken in the framework of the model approach. We need independent alternative estimates for such tests.

[16] Such a critique might seem to be more Catholic than the Pope; using the method approach for other purposes, it is not uncommon that causal statements are made on similar weak grounds. There are, however, some reasons to take such a critique seriously. First, in recent decades we have learned to be much more cautious about speaking of causal relations, because what we observe are often (at most) correlations. In this respect, some even speak of a "credibility revolution in empirical economics”. ${ }^{14)}$ Taking this into account has serious implications for how model estimates of the black economy can be employed for scientific and policy purposes. Moreover, there is at least one additional paper that employs a different approach to estimate the development of the shadow economies of different countries: employing the electricity approach, L. ONNIS and P. TIRELLI (2010) present quite different results.

[17] The model estimates of the black economy are by construction linear combinations of the explanatory variables and an error term. It is obvious that none of these explanatory variables can be employed in other models to test their impact on the black economy whenever the dependent variable comes from the model approach. ${ }^{15)}$ Such attempts are, however, sometimes performed. S.J. DAVIS and M. HENREKSON (2004) find a highly significant impact of taxation on the shadow economy, B. TORGLER and F. SCHNEIDER (2009) obtain a highly significant impact of tax morale on the shadow economy, A. DreHER, C. KotSOGIANNIS and S. MCCorRisTON (2009) find a highly significant negative impact of the GDP per capita and finally B. ENSTE (2010) reaches the same conclusion for the impact of regulation. In all four cases 'significant' results are 'found' for variables that were inputs to the construction of the dependent variable. These results are, of course, hardly astonishing; astonishing would rather be anything other than a statistically highly significant result.

[18] As long as one believes in the model, it is legitimate to use it for policy recommendations. One can, for example, suggest reducing the tax burden to reduce the size of the shadow economy. It is, however, impossible to use the same model to check whether this policy is successful. If taxes are reduced, the model will predict a shrinking of the black economy. Whether this is really the case has to be checked with an estimate of the black economy that does not use the tax burden as an explanatory variable. This not only excludes estimates of the model but also estimates of the currency demand approach. To conduct the test, we need a different procedure.

[19] As mentioned, such a study is performed by L. ONNIS and P. TIRELLI (2010), applying the electricity approach. Like all other procedures, this approach has its pros and cons. There is no reason to believe that it has fewer problems than the model approach; it might even have more. So far, however, it is the only approach that has been applied to many countries and that does not employ the tax burden in constructing the size of the shadow variable. Thus, it is at least

14. See, for example, J.D. ANGRIST and S. PISCHKE (2010). - J. SLEMROD and C. WEBER (2012) demand a similar "credibility revolution in the empirical analysis of tax evasion and the informal economy."

15. See also the corresponding critique of J. SLEMROD and C. WEBER (2012, pp. 49f.).” 
worthwhile comparing the time paths generated by the two approaches. Tremendous differences emerge. For Germany, for example, for the period from 1989/90 to 2003 L.P. FELD and F. SCHNEIDER (2010, p. 134) estimate an increase from 11.8 per cent to 17.1 per cent in relation to the GDP, whereas L. ONNIS and P. TIRELLI (2010, p. 47) predict a slight decrease from about 12 per cent in 1990 to about 10 per cent in 2005. Moreover, while L. ONNIS and P. TIRELLI show a strong decline of the German shadow economy between 1980 and 1990 from about 19 to 12 per cent of the GDP, A. BuEHN, A. KARMANN and F. SCHNEIDER (2009) report a strong increase from close to 8 per cent in 1980 to more than 12 per cent in 1990. For Germany, but also for other countries, the two approaches provide quite different general impressions: while the model estimates suggest an increase in the shadow economy during recent decades in most of the countries analysed, the electricity approach suggests a strong decrease. This difference, which is mostly pronounced for the 1990s, demands at least an explanation. On the other hand, both procedures predict rather high values, which - at least for developed countries - are hardly plausible.

\section{The Currency Demand Approach}

[20] At first glance, using the currency demand approach to calibrate the results of the model approach seems to be a natural choice; the two approaches employ more or less the same explanatory variables, and, correspondingly, the developments predicted are quite similar. It has, however, its own problems. First, it also only produces a relative measure; other exogenously given information is needed to normalise the estimates to derive figures in relation to the GDP. Typically, it is assumed that in a specific (earlier) year the black economy was (close to) zero. ${ }^{16)}$ Second, as already mentioned in the seminal paper by V. TANZI (1980), a core assumption is that the velocity of cash money is the same in the underground as in the official economy. If there is considerable money hoarding in the former, the velocity might be much smaller and, correspondingly, the estimates of the size of the black economy also become much smaller.

[21] H. Ahumada, F. Alvaredo and A. Canavese (2007) show how this assumption can be tested. They assert that it only holds when the income elasticity of the demand for money is one. They derive a correction and recalculate measures of the shadow economy for the published results of some countries. While they find higher values for developing countries, they obtain considerably lower results for developed countries: 5.1 per cent of the registered GDP instead of 8 per cent for Norway between 1952 and 1978, 1.51 instead of 6.3 per cent for Norway in 1978 and 10.4 instead of 14.82 per cent for Australia between 1967 and 2000. ${ }^{17)}$ The original estimates are taken from A. ISACHSEN, J. KLOVLAND and S. STRøM (1982), A. ISACHSEN, and S. STRøM (1985) and C. BAJADA and F. SCHNEIDER (2003). ${ }^{18)}$

16. For this problem of the 'initial condition' see also H. Ahumada, F. Alvaredo and A. CANAveSE (2008).

17. For Australia, the value 14.82 is from the working paper version (p. 21). In the final version C. BAJADA and F. SCHNEIDER (2003) report a value of 13.91 (p. 396).

18. Given their assessment "that the level of econometric analysis in these studies is rather basic and casts doubt on their results” (p. 368f.) H. AHUMADA, F. Alvaredo and A. CANAVESE (2007) "do not intend to provide accurate measures" but just show that their correction can lead to quite different results. 
[22] The currency demand approach is also criticised by K. TAKALA and M. VIREN (2010). First, they observe that the relation between banknotes and GDP was more or less stable in the 1980s and 1990s in Finland as well as in the euro area but increased strongly after 2002. Thus, in recent years there has been a dramatic increase in the cash demand, which can hardly be attributed to an increase in the shadow economy. Second, they compare F. SCHNEIDER's (2005) estimate for Finland in 1989/1990 of 13.2 per cent in relation to the GDP with the Finnish estimates, which are in the range of 1 and 2 per cent. Their main criticism is the strong implausibility of F. SCHNEIDER's estimates: “An estimate of 13.2 percent of GDP can be obtained by including all the value added of construction and the following expenditure categories in private consumption: alcohol, tobacco, transport services, restaurants and cafes, personal hygiene and beauty care. Needless to say, that this makes little sense because, for instance, smuggling of alcohol and tobacco is estimated to an amount, which is less than 1 percent of national account figures. According to most estimates, prostitution and drug trafficking account for less than 0.2 percent in Finland” (p. 529). Thus, at least for developed countries, the currency demand approach seems to produce figures that are much too high for the size of the shadow economy.

\section{Some Plausibility Checks for Germany}

[23] Does this also hold for Germany? To answer this question, we allocate the 'GDP' of the shadow economy to its different sectors and compare it with the sectors of the official economy. To estimate the structure of the German shadow economy, we rely on the data for 2001 to 2008 (approximately) provided by L.P. FELD and C. LARSEN (2012, Figure 9.1, p. 72). In their research, the shadow economy is split into eight sectors (and a residual category). To smooth the data, we use averages for the three observations given. We use the year 2005 for the comparison because it is in the middle of the observation period of the survey data. ${ }^{19)}$ The results are presented in Table 1. Two sectors dominate: agriculture and construction. The shares of both are approximately ten times as large in the shadow as in the official economy. ${ }^{20}$ )

[24] We apply this structure to L.P. FELD and F. SCHNEIDER's (2010, p. 134) estimate of 15.4 per cent in relation to the GDP for the year 2005. This leads to estimates for the shadow sectors of agriculture and construction that are approximately 80 and 50 per cent higher than those of the official economy. This is highly implausible, and it indicates that the currency demand approach that is employed to calibrate the model estimates is hardly suited to this purpose. ${ }^{21)}$

[25] An alternative is to use the survey data presented by L.P. FELD and C. LARSEN (2012, 2012a). As a lower bound of the size of the shadow economy we use the average of the extent of undeclared work at the actual prices paid as a proportion of the GDP for the years 2001 to 2007 provided by L.P. FELD and C. LARSEN (2012a, Table 7.2, p. 59). The results are presented in Table 1, column 4. The shadow agriculture and construction sectors are now approximately one-tenth of the official sectors; all the other shadow sectors are much smaller. These results

19. A different year in the period 2001 to 2008 would lead to quite similar results.

20. The data for the official economy are taken from: Statistisches Jahrbuch 2011 für die Bundesrepublik Deutschland, Table 24.7, pp. 637f. See Table A1 in the Appendix.

21. For some alternative plausibility checks see W.A.S. КосH (2007, pp. 158ff.). 
are at least not implausible, but given the fact that not all the respondents to the surveys might fully disclose their underground activities and that not all such activities are captured by these surveys, the size of the shadow economy might be severely underestimated. However, even if we apply the correction factor of 1.44 proposed by L.P. FELD and C. LARSEN (2012a, p. 61) both shadow sectors are only about 15 per cent of their official counterparts.

\begin{tabular}{|c|c|c|c|c|c|}
\hline \multirow{4}{*}{ Sector } & \multirow{4}{*}{$\begin{array}{l}\text { Share of } \\
\text { the official } \\
\text { economy } \\
\text { (1) }\end{array}$} & \multirow{4}{*}{$\begin{array}{l}\text { Share of } \\
\text { the } \\
\text { shadow } \\
\text { economy } \\
\text { (2) }\end{array}$} & \multicolumn{3}{|c|}{ Share of GDP } \\
\hline & & & \multirow{3}{*}{$\begin{array}{c}\text { Model/ } \\
\text { currency } \\
\text { demand } \\
\text { approach } \\
\text { (3) }\end{array}$} & \multicolumn{2}{|c|}{ Survey approach } \\
\hline & & & & $\begin{array}{l}\text { Lower } \\
\text { limit }\end{array}$ & $\begin{array}{l}\text { Upper } \\
\text { limit }\end{array}$ \\
\hline & & & & (4) & (5) \\
\hline Agriculture & 0.78 & 9.33 & 1.44 & 0.10 & 0.43 \\
\hline Manufacturing & 22.73 & 1.17 & 0.18 & 0.01 & 0.05 \\
\hline Construction & 3.57 & 36.36 & 5.65 & 0.39 & 1.67 \\
\hline Sales and repairs & 9.29 & 7.67 & 1.18 & 0.08 & 0.35 \\
\hline Hotels and restaurants & 1.48 & 5.00 & 0.77 & 0.05 & 0.23 \\
\hline $\begin{array}{l}\text { Transport, telecommuni- } \\
\text { cation }\end{array}$ & 5.18 & 7.50 & 1.16 & 0.08 & 0.34 \\
\hline $\begin{array}{l}\text { Financial intermediation } \\
\text { and business activities }\end{array}$ & 16.48 & 7.50 & 1.16 & 0.08 & 0.34 \\
\hline $\begin{array}{l}\text { Public and personal ser- } \\
\text { vices }\end{array}$ & 20.75 & 10.33 & 1.59 & 0.11 & 0.47 \\
\hline Unknown & & 14.83 & & 0.16 & 0.68 \\
\hline All sectors & 90.26 & 100.00 & 15.40 & 1.06 & 4.55 \\
\hline
\end{tabular}

[26] An upper bound might be derived if we base our estimates on the undeclared working hours as a proportion of the declared hours presented by L.P. FELD and C. LARSEN (2012a, Table 7.1, p. 58), assuming the same structure for the shadow economy and applying the correction factor of 1.44 . Now, the shadow sectors of agriculture and construction are close to 50 per cent of their official counterparts. This extent, though much smaller than the estimates based on the currency demand approach, is also hard to believe. It would, for example, imply that on average - one third of all streets and buildings are produced by illicit work. This indicates that the assumption behind these calculations, that the average productivity of labour is the same in the shadow as in the official economy, is hardly tenable. 
[27] As mentioned above, despite its problems, the model approach has its advantages too. Accepting that the currency demand approach - at least in this case - does not lead to plausible results, nothing speaks against employing the survey approach to calibrate the model estimates. This is performed in Table 2 for Germany and the dates presented by L.P. FELD and F. SCHNEIDER (2010, Table 13, p. 134). We employ the lower- and upper-limit estimates of Table 1. As with the model approach, the figures show an increase in the shadow economy up to 2003 and a certain decline afterwards, but the figures are much less dramatic.

\begin{tabular}{|l|ccc|}
\hline \multicolumn{3}{|c|}{ Table 2: Development of the German Shadow Economy, 1989/90 - 2007 } \\
\hline \multirow{2}{*}{ Year } & Share of GDP & Survey approach \\
& $\begin{array}{c}\text { Model/ } \\
\text { currency } \\
\text { approach }\end{array}$ & Lower limit & Upper limit \\
\hline $1989 / 90$ & 11.8 & 0.81 & 3.49 \\
$1994 / 95$ & 13.5 & 0.93 & 4.00 \\
$1997 / 98$ & 14.9 & 1.03 & 4.41 \\
$1999 / 2000$ & 16.0 & 1.10 & 4.74 \\
$2001 / 02$ & 16.3 & 1.12 & 4.83 \\
2003 & 17.1 & 1.18 & 5.06 \\
2004 & 16.1 & 1.11 & 4.77 \\
2005 & 15.4 & 1.06 & 4.56 \\
2006 & 14.9 & 1.03 & 4.41 \\
2007 & 14.6 & 1.00 & 4.32 \\
\hline
\end{tabular}

\section{Concluding Remarks}

[28] As long as it is employed cautiously enough, the model approach is a useful tool to estimate simultaneously the size and the development of the shadow economy in several countries. One major problem of this approach is, however, that a second method is necessary to calibrate the model to obtain concrete figures. In the past, the currency demand approach has mainly been used for this purpose. Nevertheless, this approach also has its problems. One needs an initial condition to calibrate it, as well as an assumption about the velocity of money in the shadow economy. The typical 'naïve' assumption that the velocity of money is equal in the two parts of the economy can lead to highly implausible results; the size of the shadow economy might be largely overestimated.

[29] An alternative is to use the survey method to calibrate the model estimates. It has the advantage that it does not have to be calibrated itself, but the true size might be underestimated. 
This can be overcome by applying a correction factor. Moreover, the survey method allows statements about the structure of the shadow economy that can be used to check the plausibility of the estimates. This is relevant insofar as the model estimates cannot be used to test whether certain variables have an impact on the shadow economy as long as these variables are used in the construction of the variable 'shadow economy'. Furthermore, because the model procedure demands that all potentially relevant inputs should be incorporated, this holds for all relevant and available variables.

[30] For real tests of whether a variable, for example the burden of taxation, has an impact on the shadow economy, procedures are necessary that do not use these variables in constructing the indicator. Thus, to make progress in analysing the shadow economy, the model approach has a role to play but has to be complemented by other methods employing different data. The currency demand approach is not suitable as long as it employs the same variables for its constructions.

\section{Literature}

Ahumada, Hildegart, Facundo Alvaredo and Alfredo Canavese (2007), The Monetary Method and the Size of the Shadow Economy: A Critical Assessment, Economics Letters 101, pp. $97-99$.

Ahumada, Hildegart, Facundo Alvaredo and Alfredo Canavese (2008), The Monetary Method to Measure the Shadow Economy: The Forgotten Problem of the Initial Conditions, Review of Income and Wealth 53, pp. $363-371$.

ANGRIST, JOSHUA D., and JÖRN-STEFFEN PISCHKE (2010), The Credibility Revolution in Empirical Economics: How Better Research Design is Taking the Con out of Econometrics, Journal of Economic Perspectives 24(2), pp. 3 - 30.

BAJADA, CHRISTOPHER, and Friedrich SCHNEIDER (2003), The Size and Development of the Shadow Economies in the Asia-Pacific, Johannes Kepler University Linz, Department of Economics, Working Paper No. 0301; published in: Pacific Economic Review 10 (2005), pp. 379 - 401.

BUEHN, ANDREAS, and FrIEDRICH SCHNEIDER (2012), Shadow Economies Around the World: Novel Insights, Accepted Knowledge, and New Estimates, International Tax and Public Finance 19, pp. $139-171$.

BuEHN, ANDREAS, ALEXANDER KARMANN and FRIEDRICH SCHNEIDER (2009), Shadow Economy and Do-it-Yourself Activities: The German Case, Journal of Institutional and Theoretical Economics 165, pp. $701-722$.

CAGAn, Philip (1958), The Demand for Currency Relative to Money Supply, Journal of Political Economy 66, pp. $303-329$.

DAVIS, Steven J., and MAgnus HenReKson (2004), Tax Effects on Work Activity, Industry Mix and Shadow Economy Size: Evidence from Rich-Country Comparisons, NBER Working Paper No. 021238, Cambridge, MA.

DreHer, AXel, Christos Kotsogiannis and SteVe MCCORRISTON (2009), How Do Institutions Affect Corruption and the Shadow Economy?, International Tax and Public Finance 16, pp. 773 - 796.

ENSTE, DOMiniK H. (2010), Regulation and Shadow Economy: Empirical Evidence for 25 OECD Countries, Constitutional Political Economy 21, pp. 231 - 248. 
ENSTE, DOMINIK H., and FRIEDRICH SCHNEIDER (2006), Jahrbuch Schattenwirtschaft 2006/2007, Lit Verlag, Wien/Berlin.

FEIGE, EdGAR L. (1979), How Big Is the Irregular Economy?, Challenge 22/6, pp. 5 - 13.

FEIGE, EDGAR L. (2015), Reflections on the Meaning and Measurement of Unobserved Economies: What Do We Really Know About the "Shadow Economy"?, Munich Personal RePEc Archive Paper No. 68466.

FELD, LaRs P., and Claus LARSEn (2005), Black Activities in Germany in 2001 and 2004, A Comparison Based on Survey Data, The Rockwool Foundation Research Unit, Copenhagen.

Feld, LaRs P., and Claus LaRSEn (2012), Das Ausmass der Schattenwirtschaft in Deutschland, University Press of Southern Denmark, Odense.

Feld, Lars P., and Claus LaRsen (2012a), Undeclared Work, Deterrence and Social Norms: The Case of Germany, Springer, Berlin/Heidelberg.

FELD, LARS P., and FRIEDRICH SCHNEIDER (2010), Survey on the Shadow Economy and Undeclared Earnings in OECD Countries, German Economic Review 11, pp. 109 - 149.

FELD, LARS P., and FRIEDRICH SCHNEIDER (2011), Survey on the Shadow Economy and Undeclared Work in OECD Countries, in: F. SCHNEIDER (2011), pp. 78 - 130.

FELD, LaRs P., ANDREAS J. SCHMidT and FRIEDRICH SCHNEIDER (2011), Deterrence Policy and the Size of the Shadow Economy in Germany: An Institutional and Empirical Analysis, in: F. SCHNEIDER (2011), pp. 409 - 440.

Frey, Bruno S., and Werner W. Pommerehne (1984), The Hidden Economy: State and Prospects for Measurement, Review of Income and Wealth 30, pp. 1 - 23.

Frey, BRuno S., and Hannelore WeCK-HANnEMANn (1984), The Hidden Economy as an Unobserved Variable, European Economic Review 26, pp. 33 - 53.

Gutmann, Peter M. (1977), The Subterranean Economy, Financial Analysts Journal 33/6, pp. 26 $27+34$.

INSTITUT FÜR DEMOSKOPIE (1975), Freizeitarbeit 1974, Studie im Auftrag der Kommission für wirtschaftlichen und sozialen Wandel, Allensbach.

IsAchSEn, ARne Jon, Jan TORE KlOVland and Steinar Strøm (1982), The Hidden Economy in Norway, in: V. TANZI (1982), pp. 209 - 231.

IsACHSEn, ARne Jon, and Steinar Strøm (1982), The Size and Growth of the Hidden Economy in Norway, Review of Income and Wealth 31, pp. 21 - 38.

JostocK, PAUL (1943), Über den Umfang des der Besteuerung entgehenden Einkommens, Weltwirtschaftliches Archiv 57, pp. 27 - 80.

KAZEMIER, BRUgT (2006), Monitoring the Underground Economy: A Survey of Methods and Estimates, in: D.H. ENSTE and F. SCHNEIDER (2006), pp. 11 - 53.

KIRCHGÄSSNER, GEBHARD (1984), Verfahren zur Erfassung des in der Schattenwirtschaft erarbeiteten Sozialprodukts, Allgemeines Statistisches Archiv 68, pp. 378 - 405.

Koch, WALTER A.S. (2007), Zum Umfang der Schattenwirtschaft in Deutschland, List Forum für Wirtschafts- und Finanzpolitik 33, pp. 153 - 172.

KLOVland, JAN TORE (1984), Tax Evasion and the Demand for Currency in Norway and Sweden: Is There a Hidden Relationship?, Scandinavian Journal of Economics 86, pp. 423 - 439.

OnNis, LuisAnNA, and PATRIZIO TIRELli (2010), Challenging the Popular Wisdom: New Estimates of the Unobserved Economy, University of Milan - Bicocca, Department of Economics, Working Paper No. 184. 
SCHNEIDER, FRIEDRICH (2005), Shadow Economies Around the World: What Do We Really Know?, European Journal of Political Economy 21, pp. 598 - 642.

SCHNEIDER, FRIEDRICH (2005a), The Size of the Shadow Economies in 145 Countries from 1999 to 2003, Brown Journal of World Affairs 11/2.

SCHNEIDER, FRIEDRICH (2011) (ed.), Handbook of the Shadow Economy, Edward Elgar, Cheltenham UK et al.

SCHNEIDER, FRIEDRICH (2015), Schattenwirtschaft und Schattenarbeitsmarkt: Die Entwicklungen der vergangenen 20 Jahre, Perspektiven der Wirtschaftspolitik 16, pp. 3 - 25.

SCHNEIDER, FRIEDRICH (2015a), Ein erneuter Anstieg der Schattenwirtschaft (Pfusch) in Österreich in 2015 sowie die Einstellung der ÖsterreicherInnen dazu, mimeo University of Linz, April.

SCHNEIDER, FRIEDRICH, and DOMINIK H. ENSTE (2000), Shadow Economies: Size, Causes, and Consequences, Journal of Economics Literature 38, pp. 77 - 114.

SCHNEIDER, FRIEDRICH, and DOMINIK H. ENSTE (2002), The Shadow Economy: An International Survey, Cambridge University Press, Cambridge UK.

Slemrod, Joel, and CARoline WeBer (2012), Evidence of the Invisible: Toward a Credibility Revolution in the Empirical Analysis of Tax Evasion and the Informal Economy, International Tax and Public Finance 19, pp. 25 - 53.

TAKALA, KARI, and MATTI VIREN (2010), Is Cash Used Only in the Shadow Economy?, International Economic Journal 24, pp. 525 - 540.

TANZI, VITO (1980), The Underground Economy in the United States. Estimates and Implications, Banca Nazionale del Lavoro Quarterly Review 135, pp, 427 - 453.

TANZI, VITO (1982), The Underground Economy in the United States and Abroad, Lexington Books, Lexington.

TORgLeR, BENNo, and Friedrich SChNEIDER (2009), The Impact of Tax Morale and Institutional Quality on the Shadow Economy, Journal of Economic Psychology 30, pp. 228 - 245.

WECK, HANNELORE (1983), Schattenwirtschaft: Eine Möglichkeit zur Einschränkung der öffentlichen Verwaltung? Eine ökonomische Analyse, Peter Lang, Bern. 
Appendix

\begin{tabular}{|l|cc|}
\hline \multicolumn{2}{|c|}{ Table A1: Gross Value Added of the German Economy, 2005 } \\
\hline Sector & Bill. EUR & Share of GDP \\
\hline Agriculture & 17.52 & 0.78 \\
Manufacturing & 509.75 & 22.73 \\
Construction & 80.14 & 3.57 \\
Sales and repairs & 208.21 & 9.29 \\
Hotels and restaurants & 33.10 & 1.48 \\
Transport, telecommunication & 116.16 & 5.18 \\
Financial intermediation and & 593.71 & 26.48 \\
business activities & 465.30 & 20.75 \\
Public and personal services & 2023.89 & 90.26 \\
\hline All sectors & 2242.20 & 100.00 \\
\hline GDP & Statistisches Jahrbuch 2011 für die Bundesrepublik Deutschland, \\
\hline Source of the data: & & \\
\hline
\end{tabular}

